\title{
Performance Evaluation and Adaptability of Food Barely (Hordeum vulgare L.) in the Highlands of Eastern Hararghe
}

\author{
Zeleke Legesse Bakana ${ }^{1 *}$, Fuad Abduselam² and Alemayehu Biri ${ }^{1}$ \\ ${ }^{1}$ Fadis Agricultural research Center, P.O.Box 904, Harar, Ethiopia \\ ${ }^{2}$ School of Plant Sciences, Collage of Agriculture and Environmental Sciences, Haramaya University, Ethiopia
}

Submission: September 06, 2018, Published: October 15, 2018

*Corresponding author: Zeleke Legesse Bakana, Fadis Agricultural research Center, Haramaya University, Harar, Ethiopia, Email: zalelegesse12@gmail.com

Fuad Abduselam, School of Plant Sciences, Collage of Agriculture and Environmental Sciences, Haramaya University, Haramaya, Ethiopia; Email: abduselamfuad@gmail.com

Alemayehu Biri, Fedis Agricultural Research Center, P.O. Box, 904 Harar, Ethiopia; Email: alex2hny@gmail.com

\begin{abstract}
Ten released Food barley varieties with one local check were tested at two sites in randomized complete block design with three replications during 2014/15 cropping season. The experiment was carried out to test the adaptability of improved food barley varieties and select the best high yielding variety/ies for the target area. The varieties used as treatments were (Guta, Harbu, Abdane, Dimtu, Shage, HB-1307, Biftu, Dafo, Dinsho and Ardu) along with one local check were evaluated at Kurfa chale and Kersa highlands of Eastern Hararghe. The Analysis of variance revealed that highly significant difference $(\mathrm{P}<0.01)$ for days to maturity, plant height, spike length and grain yield at both locations where as, significant difference $(\mathrm{P}<0.05)$ were observed at Kersa. The mean grain yield of $\mathrm{HB}-1107$, Guta and Harbu were better by $35.2 \%, 24 \%, 3.1 \%$ and $38.4 \%, 19.3 \%, 10.4 \%$ grain yield over local check at both Kurfa chale and Kersa, respectively. Similarly, the mean grain yield of Ardu $24.4 \%$ grain yield advantage over the local check at Kersa. In addition0\% logging was observed for HB-1307 at both locations which can be considered as good trait. Moreover, HB-1307 has showed better grain yield than other varieties in addition to logging resistant which might be suitable agroecology for this variety. Overall, improved variety (HB-1307) was found superior over all other varieties tested including the local variety for its grain yield on both locations. Thus, this HB-1307 variety is recommended to demonstrate with production packages in Kurfa Chale and Kersa and similar agro ecologies.
\end{abstract}

Keywords: Adaptability food barley; Grain yield and variety; Soil erosion; Morphological types, Genetic races; Agro-ecology

\section{Introduction}

Barley belongs to the genus Hordeum $L$. in the tribe Triticale of the family Poaceae. Barley is thought to have originated in the Fertile Crescent area of the Near East from the wild progenitor Hordeum spontaneous. Food barley is commonly cultivated in stressed areas where soil erosion, occasional drought or frost limits the ability to grow other crops [1]. The crop is now grown worldwide with greater concentration in temperate areas and high altitudes of tropics and subtropics. The greatest diversity of barley in terms of morphological types, genetic races, disease resistant lines and endemic morph types exists in Ethiopia.

Barley is one of the most important staple food crops in the highlands of Ethiopia. It has great importance in social and food habit of the people. The major barley producing regions are Oromia, Amhara, Tigray, Southern Nations and Nationalities which account for about $99.5 \%$ of the total annual barley production. Even though, Ethiopia has a wide range of favorable agro-ecology for cultivating
Food Barley its production is gradually limited to a few localities of western and southern highlands of Oromia. But still there are some localities which have the potential for producing the crop in the country. Among suitable areas for producing Food barley Eastern Hararghe highlands has the potential. This indicates that there are some localities which are not fully addressed to satisfy the need for maximizing yield, using high yielder, disease resistant and early maturing variety of the crop.

Food barley is fourth important crop in eastern Hararghe followed by maize, sorghum and wheat in terms of number of households $(101,994)$ producing and fifth important crop in terms of area coverage $(6,431.46 \mathrm{ha})$ followed by sorghum, maize, wheat and tef. However, productivity of food barley in eastern Hararghe is low 20.29 quintal/ha compared to regional average of Oromia 21.73 quintal/ha [2]. So far, no efforts have been made in promoting newly released food barley in eastern Hararghe even though there is great potential in the highlands of the zone. Identification of 
adaptable variety minimizes the magnitude of scale or rank shift of their performance across or specific environment [3-5]. Hence, it is important to adapt these medium to early maturing maize varieties to the study area. Thus, the present study was conducted to compare the performance of released food barely varieties for their adaptability and to recommend a suitable one for farmers of eastern Hararghe of Ethiopia and similar agro-ecologies.

\section{Materials and Methods}

\section{Experimental materials and design}

The experiment was conducted during 2014/15 main cropping season in highlands of Eastern Hararghe namely, Kurfa chale and Kersa districts. Ten improved food barley varieties released from agricultural research centers in the country were collected and evaluated. The varieties are namely Guta, Harbu, Abdane, Dimtu, Shage, HB-1307, Biftu, Dafo, Dinsho and Ardu and one local check were evaluated. The trial was laid down in RCBD design with two sites as replication and each treatment receiving the same management. Each variety was planted in three replications and with plot size of $2 \mathrm{~m} \times 3 \mathrm{~m}$.

The food barley seeds were drilled in a $3-4 \mathrm{~cm}$ depth with spacing of $0.2 \mathrm{~m}$ between rows. These genotypes were randomly assigned to each plot separated by $1 \mathrm{~m}$ blocks and $0.5 \mathrm{~m}$ between plots. Hundred kg ha-1 Urea and DAP (Di Ammonium Phosphate) were used as a source of Nitrogen and Phosphorous respectively. Half of the urea fertilizer and the whole DAP were applied at the time of planting while the remaining Urea was applied after four weeks of emergence.

\section{Data collection}

Data collected during the growing season were days to $50 \%$ maturity, plant height $(\mathrm{cm})$, spike length $(\mathrm{cm})$, seed per spike and grain yield $\left(\mathrm{kg} \mathrm{ha}^{-1}\right)$. Data collected on individual plant basis from five randomly selected plants were, plant height $(\mathrm{cm})$, spike length $(\mathrm{cm})$ and seed per spike. The randomly selected plants were carefully uprooted at physiological maturity to measure growth parameters. Data collected on plot basis were logging \%, days to maturity and grain yield $\left(\mathrm{kg} \mathrm{ha}^{-1}\right)$.

\section{Statistical data analysis}

Analysis of variance for the design was carried out using SAS 9.0 software for the parameters studied following the standard procedures outlined by [6]. The level of significance used in ' $F$ ' and ' $t$ ' test was $P=0.05$. When the treatment effects were found to be significant, the means were separated using the Fisher's protected least significant test was $\mathrm{P}=0.05$.

\section{Results and Discussion}

The Analysis of variance revealed that highly significant difference $(\mathrm{P}<0.01$ ) for days to maturity, plant height, spike length and grain yield at both locations whereas, significant difference $(\mathrm{P}<0.05)$ were observed at Kersa and non-significant difference were observed for seed per spike at Kurfa chale during the study (Table $1 \& 2$ ). Even though there were no significant differences for number of seeds per spike obtained at $(\mathrm{P}<0.05)$ at Kurfa chale, there was a slight numerical difference between them. Generally, the variation observed among varieties for the studied parameters are might be due to genetic variation.

Table 1: The mean squares for different sources of variation and the corresponding CV (\%) for 5 characters studied at Kurfa chale, in $2014 / 15$ cropping season.

\begin{tabular}{|c|c|c|c|c|c|c|}
\hline S.V & DF & DM & PH & SL & SPS & GY \\
\hline Rep & 2 & 0.2121 & 7.46 & 0.2666 & 3.39 & 6.38 \\
\hline Variety & 10 & $84.5394^{* *}$ & $82.01^{* *}$ & $6.9962^{* *}$ & 50.99 NS & $165.17^{* *}$ \\
\hline Error & 20 & 0.3121 & 19.77 & 0.3481 & 38.96 & 14.71 \\
\hline Total & $\mathbf{3 2}$ & & & & \\
\hline LSD (P <0.05) & & 0.9515 & 7.573 & 1.005 & NS & 6.533 \\
\hline CV (\%) & & 0.8 & 4.6 & 8.3 & 13.4 & 13.7 \\
\hline
\end{tabular}

$\mathrm{S} . \mathrm{V}=$ Source of variation; DF= Degree of freedom DM= Days to $50 \%$ Maturity; PH= Plant Height; SL= Spike length, SPS= Seed per spike; GY= Grain yield kg/ha.

Table 2: The mean squares for different sources of variation and the corresponding CV (\%) for 5 characters studied at Kersa, in $2014 / 15$ cropping season.

\begin{tabular}{|c|c|c|c|c|c|c|}
\hline S.V & DF & DM & PH & SL & SPS & GY \\
\hline Rep & 2 & 0.576 & 19.41 & 0.13604 & 104.12 & 6.38 \\
\hline Variety & 10 & $121.824^{* *}$ & $271.67^{* *}$ & $1.63053^{* *}$ & $162.36^{*}$ & $165.17^{* *}$ \\
\hline Error & 20 & 1.942 & 38.56 & 0.02732 & 63.32 & 14.71 \\
\hline Total & $\mathbf{3 2}$ & & & & \\
\hline LSD (P<0.05) & & 2.374 & 11.296 & 0.301 & 13.55 & 6.533 \\
\hline CV (\%) & & 1.6 & 6.2 & 2.6 & 19.5 & 13.7 \\
\hline
\end{tabular}

$\mathrm{S} . \mathrm{V}=$ Source of variation; DF= Degree of freedom; DM= Days to $50 \%$ Maturity; PH= Plant Height; SL=Spike length; SPS= Seed per spike; $\mathrm{GY}=$ Grain yield kg/ha. 


\section{Agricultural Research \& Technology: Open Access Journal}

The results revealed that the tallest plant height was obtained by Shage measuring $109.07 \mathrm{~cm}$ followed by Dimtu, local, HB1307 and Harbu variety with 100.89, 100.84, 99.34 and $98.64 \mathrm{~cm}$ respectively and the shortest plant height obtained were 89.17 , 93.56 and $93.63 \mathrm{~cm}$ from Dinsho, Biftu and Ardu varieties at Kurfa chale respectively (Table 3). On the other hand, variety Ardu and HB-1307 was the longest and Abdane and Dafo was the shortest in terms of height measuring $120,108.5$ and $86.3,88.5 \mathrm{~cm}$ respectively, as compared tested varieties at Kersa (Table 3). Earliest days to $50 \%$ maturity were recorded on Dinsho and Biftu varieties with 66 days, at Kurfa chale and 76.67 and 81.33 days for Dinsho and Dafo varieties at Kersa respectively, while latest days to $50 \%$ maturity were recorded on Ardu varieties at both locations taking 100 and 81.67 days at Kersa and Kurfa chale respectively.

Table 3: Mean comparison of grain yield and other parameters of highland food barley at both location Variety Kurfa Chale and Kersa.

\begin{tabular}{|c|c|c|c|c|c|c|c|c|c|c|}
\hline \multirow{3}{*}{ Varieties } & \multicolumn{10}{|c|}{ Location } \\
\hline & \multicolumn{5}{|c|}{ Kurfa Chale } & \multicolumn{5}{|c|}{ Kersa } \\
\hline & DM & PH & SL & SPS & GY & DM & PH & SL & SPS & GY \\
\hline Dinsho & $66 f$ & $89.17 \mathrm{c}$ & $8.7 \mathrm{a}$ & 49 & $1825.6 \mathrm{ef}$ & $76.67 \mathrm{~g}$ & $96.2 \mathrm{cde}$ & $6.282 \mathrm{~d}$ & $33.67 \mathrm{~cd}$ & $1584 f$ \\
\hline Shage & $81 a$ & $109.07 a$ & $6.8 \mathrm{~b}$ & 45.7 & 2082.1e & $92 c$ & $97.6 \mathrm{cde}$ & $4.933 \mathrm{f}$ & 36.33bcd & 2300de \\
\hline Guta & $71.67 \mathrm{c}$ & $98.03 \mathrm{~b}$ & $8.9 a$ & 51 & $3646.2 \mathrm{~b}$ & $87.67 \mathrm{e}$ & $104.5 b c$ & $6.583 c$ & $30 d$ & $3304 b c$ \\
\hline Dimtu & $76 b$ & $100.89 \mathrm{~b}$ & $8.3 \mathrm{a}$ & 46.3 & $2112.8 \mathrm{e}$ & $96.33 b$ & $102.3 \mathrm{bc}$ & $6.1 \mathrm{de}$ & $37 \mathrm{bcd}$ & 2561de \\
\hline Dafo & $71 \mathrm{~cd}$ & $94.87 \mathrm{bc}$ & $8.3 a$ & 38 & 1518.0f & $81.33 \mathrm{f}$ & $88.5 \mathrm{de}$ & $6.9 \mathrm{ab}$ & $35.67 \mathrm{~cd}$ & $2068 \mathrm{ef}$ \\
\hline Abdane & $70 \mathrm{e}$ & $95.22 b c$ & $6.0 \mathrm{bc}$ & 47 & 2312.8de & $90.33 \mathrm{~cd}$ & $86.3 \mathrm{e}$ & 7.1a & 44.67abc & 2831cd \\
\hline Harbu & 70.67de & $98.64 b$ & $6.7 \mathrm{~b}$ & 48.7 & $2835.9 c$ & $87 \mathrm{e}$ & $105.3 \mathrm{bc}$ & $5.883 \mathrm{e}$ & $47 a b c$ & 2918bcd \\
\hline HB-1307 & $76 b$ & $99.34 b$ & $8.8 \mathrm{a}$ & 53.7 & 4241.0a & $91 \mathrm{~cd}$ & $108.5 \mathrm{~b}$ & 7.1a & $54 a$ & $4328.5 a$ \\
\hline Ardu & $81.67 a$ & $93.63 \mathrm{bc}$ & $5.0 \mathrm{c}$ & 43.3 & $2661.5 \mathrm{~cd}$ & $100 a$ & $120.8 \mathrm{a}$ & $6.733 \mathrm{bc}$ & $49.33 \mathrm{ab}$ & $3536.6 \mathrm{~b}$ \\
\hline Biftu & $66 f$ & $93.56 \mathrm{bc}$ & $5.6 \mathrm{c}$ & 45.7 & $2553.9 \mathrm{~cd}$ & 89.33de & $100.0 \mathrm{bc}$ & $6.15 \mathrm{de}$ & 43.33abcd & 2667cde \\
\hline Local & 70.33de & $100.84 b$ & $5.2 \mathrm{c}$ & 44.3 & $2748.7 \mathrm{c}$ & 89de & $97.8 \mathrm{bcd}$ & $5.1 \mathrm{f}$ & 38.33bcd & $2667 \mathrm{cde}$ \\
\hline CV\% & 0.8 & 4.6 & 8.3 & 13.4 & 1.6 & 8.4 & 6.2 & 2.6 & 19.5 & 13.7 \\
\hline LSD (0.05) & 0.9515 & 7.573 & 1.005 & NS & 371.08 & 2.374 & 11.296 & 0.301 & 13.55 & 6.533 \\
\hline
\end{tabular}

${ }^{*} \mathrm{p}<0.05$ and NS =not significant; DM= Days to $50 \%$ maturity; PH= Plant height; SL= Spike length; SPS= Number of Seed per spike; GY= Grain Yield kg per hector.

On the other hand, longest spike length was recorded on Guta, HB-1307, Dinsho, Dimtu and Dafo measuring 8.9,8.8, 8.7, 8.3 and $8.3 \mathrm{~cm}$ respectively while shorter spike length recorded were 5, 5.2 and $5.6 \mathrm{~cm}$ from Ardu, Local and Biftu respectively at Kurfa chale. In contrary, $7.1,7.1$ and $6.9 \mathrm{~cm}$ of spike length were obtained from HB-1307, Abdane and Dafo as highest value and 4.9,5.1 and $5.8 \mathrm{~cm}$ as shortest spike length respectively at Kersa (Table 3). At the mean time although, seed per spike were not-significant highest and lowest number of seed per spike were counted from HB-1307 (53.7) and Dafo (38) at Kurfa chale. However, again the highest seed per spike were obtained from HB-1307 (54) during the study.

In the same way highest grain yield were obtained from HB1307 at both locations giving 4241 and $4328.5 \mathrm{~kg} \mathrm{ha}^{-1}$ at Kurfa chale and Kersa respectively, as also reported by [7]. The secondbest variety were Guta and Ardu at Kurfa chale and Kersa yielding 3646.2 and $3536.6 \mathrm{~kg} \mathrm{ha}^{-1}$ respectively while the lowest yield was recorded from Dafo (1518kg ha-1) and Dinsho (1825.6kg ha-1) at Kurfa chale and variety Dinsho (1584kg ha-1) and Dafo (2068kg $\mathrm{ha}^{-1}$ ) at Kersa during the study (Table 3 ).

Generally, the mean grain yield of HB-1307, Guta and Harbu gave $35.2 \%, 24 \%, 3.1 \%$ and $38.4 \%, 19.3 \%, 10.4 \%$ grain yield advantage over the local check at both Kurfa chale and Kersa, respectively. Similarly, the mean grain yield of Ardu gave $24.4 \%$ higher grain yield advantage over the local check at Kersa. Along food barley varieties tested HB-1307, Guta and Harbu were performed well in terms of yield and other agronomic parameters.

This result is in line with Sinana Agricultural Research Center (SARC) which reported potential yield for Shage variety were 2.15.1 ton ha ${ }^{-1}$ grain during the release of the variety [8], and 3.37ton ha $^{-1}$ were reported by [7]. Similarly, 2.3-4, 3.6-6.3 and 4.8ton ha ${ }^{-1}$ grain yield potential was reported for Dimtu, Ardu and HB- 1307 respectively $[9,10]$. However, this result varies from the study conducted by [11], in Bale highlands which reported 2.3ton ha-1 which is a little bit lower compared to this finding which might be suitable environment for the variety in the study area.

This might be variation between the two environments. Food barley varieties used in the present study had diverse genetic composition and as a consequence produced results in the parameters studied. Overall, the variation in plant height, days to maturity, spike length, seed per spike and grain yield observed were due to differences among the variety. However, the variation observed in the parameters studied compared to other location is environmental. Tahir et al. [12], reported that plant height is genetically as well as environmental controlled factor; however, the selection of proper crop cultivar manages the influence of environment.

Additionally, logging percentage were considered as a criteria along with other agronomic yield and yield related traits to 
select best suitable variety/ies for the areas and were scored in percentage (Table 4). As clearly illustrated in the table $0 \%$ logging were observed for HB-1307 at both location which can be considered as good trait and make this variety more preferable.

Moreover, HB-1307 has showed better grain yield than other varieties in addition to logging resistant which might be suitable

Table 4: Mean score of logging percentage of highland food barley tested at both location during 2014/15 season.

\begin{tabular}{|c|c|c|c|c|c|c|c|c|c|c|c|}
\hline \multirow{2}{*}{ Site } & \multicolumn{11}{|c|}{ Variety } \\
\hline & Guta & Abdane & Shage & Ardu & Dimtu & Local & Dinsho & HB-1307 & Harbu & Dafo & Biftu \\
\hline K/chale & 90 & 85 & 50 & 50 & 50 & 75 & 100 & 0 & 85 & 100 & 100 \\
\hline Kersa & 50 & 50 & 0 & 50 & 0 & 50 & 50 & 0 & 100 & 50 & 85 \\
\hline
\end{tabular}

\section{Summary and Conclusion}

The experiment was conducted in 2014/15 main cropping season at two locations of Kurfa chale and Kersa districts to select food barley varieties that have a good performance in terms of yield and other different parameters to the area. Overall, improved variety (HB-1307) was found superior over all other varieties tested including the local variety for its grain yield on both locations. Thus, this variety is recommended for production at Kurfa chale, Kersa and similar agro ecologies of eastern Hararghe.

\section{Acknowledgment}

The authors would like to thank the Oromia Agricultural Research Institute, Fadis Agricultural Research Center for financing and providing working facility. We would like also to thank Kurfa chale and Kersa district bureau of agriculture for allowing their land to accomplish the activity.

\section{References}

1. Berhane Lakew, Hailu Gebre, Fekadu Alemayehu (2005) Barley production and research in Ethiopia. pp. 1-8.

2. Central Statistical Agency (CSA) Agricultural sample survey 2013/14 (2006 E.C.) (September to December 2009), Report on Area and Production of Crops (Private Peasant Holdings, Meher Season). Addis Ababa, Ethiopia.

3. Dia M, Wehner TC, Hassell R, Price DS, Boyhan GE, et al. (2016a) Genotype $\mathrm{x}$ environment interaction and stability analysis for watermelon fruit yield in the U.S. Crop Sci 56: 1645-1661. agro-ecology for this variety. Additionally, $0 \%$ was seen for Dimtu and Shage at Kersa, although 50\% logging were scored for both varieties at Kurfa chale (Table 4). Overall, 100\% logging were scored from Dinsho, Dafo and Biftu at Kurfa chale and variety Harbu at Kersa. The variation observed between varieties over location might be due to soil type difference, environment and varietal response over environment.
4. Dia M, Wehner TC, Hassell R, Price DS, Boyhan GE, et al. (2016b) Values of locations for representing mega-environment and for discriminating yield of watermelon in the US. Crop Sci 56(4): 1726-1735.

5. Dia M, Wehner TC, Arellano C (2016c) Analysis of genotype $x$ environment interaction (GxE) using SAS programming. Agron J 108(5): 1838-1852.

6. Gomez KA, Gomez AA (1984) Statistical Procedures for Agricultural Research. ( $2^{\text {nd }}$ edn), John Wiley and Sons, New York, USA, pp. 784.

7. Mulatu B, Grando S (2011) Barley Research and Development in Ethiopia. Proceedings of the $2^{\text {nd }}$ National Barley Research and Development Review Workshop. 28-30 November 2006, HARC, Holetta, Ethiopia. ICARDA, Aleppo, Syria, pp. 391.

8. (1996) MoA, Animal and Plant Health Regulatory Directorate: Crop Variety Register, Issue No 1, Addis Ababa, Ethiopia.

9. (2001) MoA, Animal and Plant Health Regulatory Directorate: Crop Variety Register, Issue No 3, Addis Ababa, Ethiopia.

10. (2006) MoA, Animal and Plant Health Regulatory Directorate: Crop Variety Register, Issue No 8, Addis Ababa, Ethiopia.

11. Ayalneh Tilahun, Zerihun Jalata, Amare Biftu (2009) Registration of Guta Barley (Hordeium vulgare L.) Variety for Bale Highlands. East African Journal of Sciences 3(1): 108-110.

12. Tahir M, Tanveer A, Ali A, Abbas M, Wasaya A (2008) Comparative yield performance of different maize (Zea Mays L.) Hybrids under local conditions of Faisalabad-Pakistan. Pak J Life Soc Sci 6: 118-120.

\section{Your next submission with Juniper Publishers will reach you the below assets}

- Quality Editorial service

- Swift Peer Review

- Reprints availability

- E-prints Service

- Manuscript Podcast for convenient understanding

- Global attainment for your research

- Manuscript accessibility in different formats

( Pdf, E-pub, Full Text, Audio)

- Unceasing customer service

Track the below URL for one-step submission https://juniperpublishers.com/online-submission.php 